\title{
Ascending placentitis in the mare
}

\author{
Ascenderende placentitis bij de merrie
}

\author{
J. Govaere, K. Roels, C. Ververs, M. Van de Velde, V. De Lange, I. Gerits, M. Hoogewijs, \\ A. Van Soom \\ Department of Reproduction, Obstetrics and Herd Health \\ Faculty of Veterinary Medicine, Ghent University, Salisburylaan 133, B-9820 Belgium
}

Jan.Govaere@Ugent.be

\begin{abstract}
$\Lambda_{\text {bstract }}$
Ascending placentitis in the mare, which affects 3 to $7 \%$ of pregnancies, is a common cause of abortion, premature birth and delivery of compromised foals (Troedsson, 2003; LeBlanc, 2010). Since the infection ascends from the caudal genital tract, the first and most distinct lesions are seen near the caudal pole area of the allantochorion adjacent to the cervix.

The symptoms are not always obvious or will be exhibited only at a later stage of the disease process, which renders timely adequate treatment difficult. Moreover, experimental models of placentitis in the mare are difficult to maintain and double-blind, controlled studies are scarce, making it hard to formulate clear science-based advice. In this paper, the diagnosis is discussed on the basis of the symptoms, the ultrasound examinations and the endocrinological parameters, and the therapeutic and prognostic considerations are evaluated.
\end{abstract}

\section{SAMENVATTING}

Een ascenderende infectie van de placenta wordt bij 3 tot $7 \%$ van de drachtige merries gezien. Het is een veel voorkomende oorzaak van abortus, premature geboorte en zwak geboren veulens (Troedsson, 2003; LeBlanc, 2010). Gezien de infectie opklimt vanuit de caudale geslachtstractus, zijn de eerste zichtbare en meest uitgesproken letsels te vinden ter hoogte van de caudale pool van het allantochorion waar dit tegen de baarmoedermond aan ligt.

De symptomen zijn niet altijd even duidelijk of worden pas heel laat in het ziekteproces opgemerkt. Dit maakt een tijdige diagnose en initiatie van therapie uitermate moeilijk. Experimentele modellen om placentitis te bestuderen zijn moeilijk te managen en dubbel-blindexperimenten met controlegroepen zijn zeldzaam, waardoor het moeilijk is "evidence-based" advies te formuleren. In dit artikel wordt de diagnose, gebaseerd op de symptomatologie en het echografisch en endocrinologisch onderzoek, besproken en worden enkele therapeutische en prognostische aspecten benadrukt.

\section{INTRODUCTION}

Although the incidence of placentitis in pregnant mares is low, i.e. between 3 and 7\%, it may lead to abortion, stillbirth or the birth of weak foals (Giles et al., 1993; Hong et al., 1993a; Barr, 2005) (Figure 1). Besides the costs of extra neonatal care, which is often necessary when a viable foal is born, stillbirth and abortion lead to loss of income and the affected mare may be subfertile in the subsequent breeding season. Of all abortions, premature deliveries and perinatal deaths in horses, about 10 to $30 \%$ can be attributed to placentitis. As such, placentitis is a common cause of perinatal mortality (Giles et al., 1993; Hong et al., 1993b; Smith et al., 2003; Troedsson, 2003; Laugier et al., 2011; Lyle, 2014).

Pathologically, three different forms of placentitis are described, namely ascending, diffuse and focal placentitis (Zent et al., 1999). Ascending placentitis, which is caused by bacteria ascending through the vagina and infecting the placenta, is the most prevalent form of placentitis (Platt, 1975a; Whitwell, 1988; Hong et al., 1993a; Zent et al., 1999).

Placentitis is mostly of bacterial origin, but in 


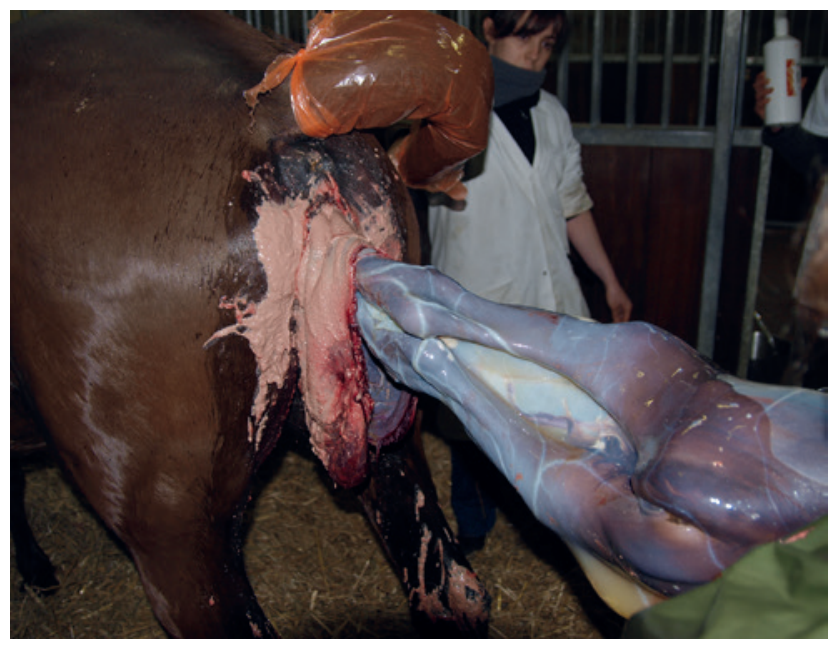

Figure 1. Placenta lesions in a placentitis case. Placental lesions and mucoid discharge at the level of the cervical star with a thickened allantochorion in a mare with placentitis and premature delivery of a compromised foal.

about $15 \%$ of cases, a fungal or mixed infection is seen (Smith et al., 2003). Most commonly, opportunistic bacteria from the lower reproductive tract of the mare are involved, with mainly Streptococcus equi subsp zooepidemicus isolated, in addition to Escherichia coli, Klebsiella pneumonia and Pseudomonas aeruginosa (Platt, 1975b; Merkt, 1985; Hinrichs et al., 1988; Whitwell, 1988; Acland, 1993; Lyle, 2014).

In the majority of cases, the affected mares are pluriparous and may have anatomic defects of the genital tract, such as pneumo- or urovagina and/or cervical incompetence (Platt, 1975b; Macpherson and Bailey, 2008; LeBlanc, 2010; Löf et al., 2014). No breed predisposition has been noted. However, due to breeding regulations and policies, Thoroughbreds might be overrepresented (Macpherson and Bailey, 2008a).

The infection, which ascends from the caudal genital tract and is facilitated by poor perineal conformation and/or cervical incompetence, is initiated at the cervical pole (Whitwell, 1988; Mays et al., 2002). In most cases, ascending placentitis occurs in the last trimester of gestation, when traction of the enlarged uterus may aggravate conformational abnormalities and the malfunctioning of the pelvic diaphragm, cervix and perineum. As a result of the infection, the fetal membranes become edematous and thickened, and they might separate from their attachment to the uterus (Platt, 1975b). The infection or the inflammation of the placental membranes alone causes a decreased functionality of the membranes, the release of pro-inflammatory cytokines, such as TNF $\alpha$, IL-1 $\beta$, IL-6 and IL-8 from placental and fetal tissues (Dudley, 1997; LeBlanc et al., 2002; Mays et al., 2002) and, together with cortisol from the mare, activation of the fetal hypothalamo-pituitary-adrenal-axis (HPA) and an increase in fetal cortisol (Challis et al., 2000). This increase in cortisol decreases 15 -hydroxy prostaglandin dehydrogenase (PGDH), which in turn leads to increasing prostaglandine (E2 and F2alpha) concentrations (LeBlanc et al., 2002; McGlothlin et al., 2004). The pro-inflammatory cytokines also increase the cyclo-oxygenase -2 (COX-2) activity (Lyle, 2014), which in turn increases the synthesis of prostaglandins. As a result of the decrease in prostaglandin dehydrogenase (PGDH) and the premature increase of COX-2, PGE2 and PGF2alpha, myometrial contractions and premature labor occur (Keelan et al., 1997; Romero et al., 1998; Gravett et al., 2000; Gibb and Challis, 2002). Thus, it is the inflammation, which is a consequence of the infection, that induces premature abortion or preterm delivery of the fetus rather than the bacterial infection per se (Pollard and Mitchell, 1996, Leblanc et al., 2002; Mays et al., 2002; McGlothlin et al., 2004; Lyle, 2009). The above described pathway, however, is a simplification of the complex mechanisms leading to abortion; for a more detailed description of the pathogenesis of placentitis, the authors refer to Lyle (2014).

There is a scarcity of evidence-based medicine to support the development of therapeutic approaches, since not only are experimental infection trials expensive and difficult to maintain, most mares also abort without any warning symptoms, since placentitis in a clinical setting externalizes itself as an insidious, hidden disease for which the diagnosis often comes too late (Macpherson and Bailey, 2008a). Moreover, endocrine regulation in the late-term mare differs from that in other species, with only subtle serum changes occurring very late in gestation, just before expulsion.

\section{SYMPTOMS}

Early diagnosis enables rapid intervention and improves the prognosis and pregnancy outcome. Unfortunately, in most cases, the diagnosis is difficult to make since the mares are rarely ill, and they do not have abnormal blood counts or changes in clinical parameters. The earliest sign, vaginal discharge, is not seen in every case (Renaudin et al., 1999; Morris et al., 2007; Macpherson and Bailey, 2008a) and the subsequent premature development of the udder is not a constant sign (Zent et al., 1999; LeBlanc et al., 2002; Morris et al. 2007; Bailey et al., 2010; LeBlanc, 2010). Although in some cases, no symptoms at all can be seen externally, even in cases, where premature udder development is seen without vaginal discharge, the mare must be checked for the presence of twins, for nocardioform (focal) placentitis and for ascending placentitis (LeBlanc, 2010).

Vaginal exploration, whether manually or through a speculum, is contraindicated. The vestibule of the mare harbors a variety of germs that may be pushed to the cranial part of the vagina during such an examination (Hinrichs et al., 1988; Bucca and Fogarthy, 2011) (Figures 2A and 2B). Moreover, an accidental mechanical stimulation of the cervix during such an 

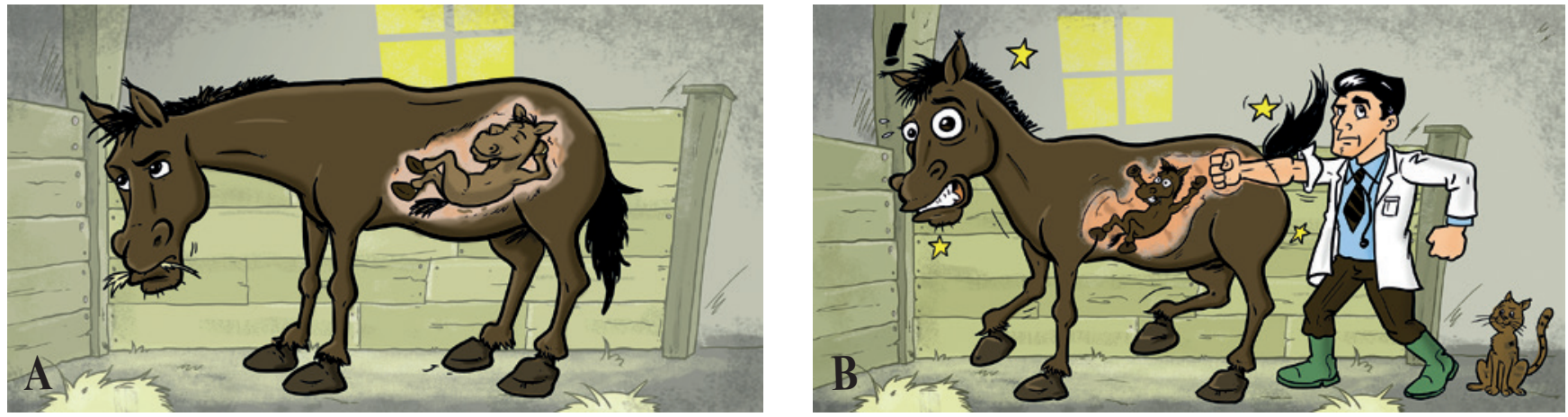

Figures $2 \mathrm{~A}$ and $\mathrm{B}$. A vaginal exploration is contraindicated. The vestibule harbors a variety of germs that may be pushed to the cranial part of the vagina. Moreover, stimulation of the cervix during such an examination can induce premature parturition.

examination can induce premature parturition (Handler et al., 2003). The tone, size and patency of the cervix can be assessed in a non-invasive way by rectal palpation and ultrasonography. The degree of cervical relaxation can be helpful for estimating the prognosis of the affected gestation. However, in mares, from the tenth month on, cervical scores (assessing length, width, echoic characteristic and tone) approach 'prepartum scores' and are, as such, only of limited use in late gestation (Bucca and Fogarthy, 2011).

\section{ULTRASONOGRAPHY}

The combined thickness of uterus and placenta (CTUP) can be measured by transrectal ultrasonography using a linear probe $(5-7.5 \mathrm{MHz})$ at the ventral portion of the placenta just cranially to the cervix. This is easier to perform when using the vasculature of the uterine branch of the vaginal artery, with its course ventral to the uterine border a little bit to the lateral side (on both sides), as a landmark (Renaudin et al., 1997; Macpherson 2006; Bucca and Fogarthy, 2011) (Figures 3A and 3B). As such, one measures always at the same location, and the hypoechoic area of the blood vessel makes it easier to visualize the contours of the uteroplacental delineation. In a normal gestation, the placenta cannot be distinguished from the uterine wall (Macpherson, 2006), although this also depends on the time of gestation (more obvious at the end of term) and the resolution of the ultrasound equipment used.

The CTUP thickens physiologically with increasing gestational age (Renaudin et al., 1997; Kelleman et al., 2002; Morris et al., 2007). A pathologically thickened CTUP can be seen in an inflamed placenta and the separation of the allantochorion from the uterine wall may become visible. Sometimes, fluid and pus can be seen between the chorion and the uterus in more advanced cases of placentitis (LeBlanc et al., 2004). In short, a CTUP of more than $1.2 \mathrm{~cm}$ at eleven months of gestation, or more than $1.5 \mathrm{~cm}$ at twelve months of gestation, may be associated with placentitis (Renaudin et al., 1997; Troedsson et al., 1997; Troedsson, 2001; Bucca et al., 2005, Bucca 2006). The thickening can develop quite rapidly, depending on the degree of contamination and inflammation, and in infectious trials, it has been observed within 7 to 48 hours post inoculation (Renaudin et al., 1999; Bailey et al., 2012).
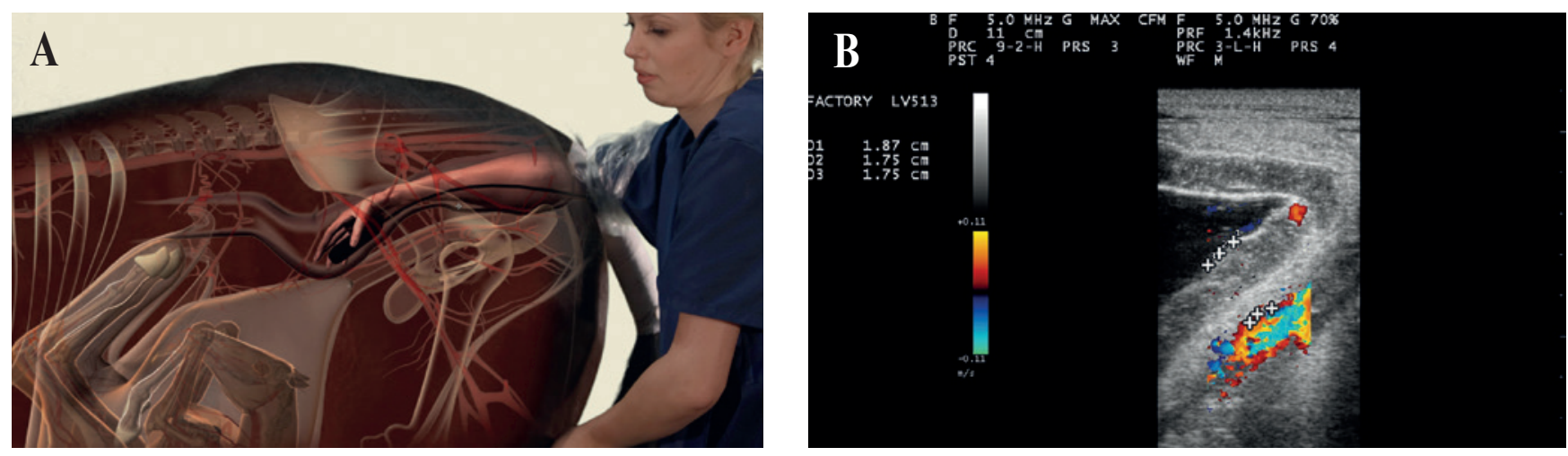

Figure $3 \mathrm{~A}$. The measurement is taken just cranial of the cervix at the level of the arterial communication between a branch of the a. vaginalis and a. uterine media as a landmark. B. Transrectal ultrasonographic image of the combined thickness of uterus and placenta (CTUP) in a placentitis case. Transrectal ultrasonographic image of the CTUP (in between +-+). Increased thickness (depending on gestational age), the presence of edema and/or placental separation from the uterine wall can be indications of placentitis. 
In some studies (Morris et al., 2007; Bailey et al., 2010; Löf et al., 2014), no different CTUP measures between mares with or without placentitis were seen, which led the authors to the conclusion that CTUP is not a good indicator of ascending placentitis during the final month of gestation in Thoroughbred mares (Löf et al., 2014). However, if an increase in CTUP is seen, a degree of placental insufficiency may be present (Cummins et al., 2008), but also other reasons of thickened placenta should be considered (e.g. fescue toxicosis, twin gestation) (Hudson et al. 2005; Govaere et al., 2009; Souza et al. 2010). Moreover, Souza et al. (2010) concluded that CTUP measurement in mares should not be the only parameter used to estimate placental failure and impending abortion.

Bailey et al. (2012) evaluated the use of Doppler measurements to diagnose placentitis in a clinical setting. However, since the onset of the disease occurs when the uterine blood flow is already very high, no differences can be detected between affected and healthy cases; therefore this parameter should not be used.

Not only the aspect and size of the CTUP have to be checked, also the appearance of the fetal fluids should be evaluated. Cloudy allantoic fluids in the last three months of gestation may indicate infection (LeBlanc, 2010), although in a study by Renaudin et al. (1999), no echoic changes were noted, neither in the amniotic nor in the allantoic fluid of the affected mares. While the fetal fluids are being checked, the fetal viability parameters (e.g. movement and heart rate) should also be assessed (LeBlanc, 2010). Repeated ultrasound measurements and check-ups are necessary to minimize the risk of error, since abrupt fetal movements can also cause the whirling up of cellular material, which produces a high density of vernix without clinical implications (Macpherson and Bailey, 2008a).

The well-being of the fetus and the extent of the inflammation should be evaluated not only on the basis of the symptoms in the mare, but also on the basis of the transrectal and transabdominal ultrasound examinations of the placenta, fetal fluids and fetus, and of the serum hormone profiles (LeBlanc, 2010).

\section{ENDOCRINE PROFILES ASSOCIATED WITH PLACENTITIS}

In the last trimester of pregnancy, the feto-placental functionality plays an important role in the endocrine regulation of pregnancy and parturition. Endocrine profiles in the late-term pregnant and periparturient mare are the result of a delicate interplay of changing hormone levels and interactions that must coincide all in a timely and concerted manner to ensure a smooth birth of a viable foal. Any condition that affects the functionality of the fetus or the placenta also alters the endocrine production, thus possibly disrupting this interaction. The feto-placental functionality can be monitored by measuring progestins and/or estrogens (Ousey, 2006; Morris et al., 2007). However, while the disease process can alter the endocrine pathways and stimulate inflammatory and immune responses, these alterations are only usable for diagnosis after the fact (Rossdale et al., 1991; Santschi et al., 1991; Ousey et al., 2004, 2006; LeBlanc, 2010).

When looking at progestin levels, it is advised to evaluate at least three consecutive samples obtained within a two- to three-day interval (Morris et al., 2007). Different abnormalities in progestin patterns have been described (LeBlanc, 2010). In short, a premature rapid decline is observed in acute conditions with imminent fetal expulsion or in the event of a dead fetus (Ousey, 2006). An early rise in progestin serum concentrations is associated with placental pathology or fetal stress (Rossdale et al., 1992; Ousey et al., 2006; Morris et al., 2007). When these elevated progestin concentrations are maintained for two to three weeks prior to the $310^{\text {th }}$ day of gestation, then a certain degree of fetal HPA activation can be assumed. These foals are more likely to survive than those that have not had this period of activation (Le Blanc, 2010). Another abnormality in the progestin pattern is the failure to exhibit the normal prepartum rise in progestin level, as is seen almost exclusively in mares after ergopeptine alkaloid exposure (fescue toxicosis) (Brendemuehl et al., 1995).

In the mare, maternal progestin concentrations are low until three weeks before parturition, when they start to rise with a subsequent abrupt decrease 24 hours before parturition (Ousey et al., 2003). This rise is associated with the onset of mammary electrolyte secretion while the fall in concentration is simultaneous with the rise in fetal cortisol levels (LeBlanc, 2010). These alterations in electrolyte concentrations in mammary secretions can be used to predict fetal readiness in the normal, a term mare. However, in preterm mares, it can be an indicator of impending abortion (Ousey et al., 1984; Rossdale et al., 1991).

In most commercial assays (RID and ELISA), progestin cross-reacts with progesterone and as such can be used to assess progestin concentration in the mare. However, the cross-reactivity of a test may differ, resulting in different progestin concentrations measured. Of the three tested commercial laboratories in Belgium, only one lab was able to detect the total progestin concentrations alongside the progesterone concentration (Figure 4). Therefore, it is essential to know the concentration in normal pregnant mares of the assay used, in order to discriminate concentration changes in placentitis cases (Ousey, 2006).

Progestin values of between 2 and $12 \mathrm{ng} / \mathrm{ml}$ are found up until the last three weeks in uncompromised gestations (Ousey et al., 2005; Morris et al., 2007), and consecutive samples vary less than $15 \%$ within a 24-hour period (Morris et al. 2007). Decreased progestin levels are indicative of compromised foals, 
Progestagen measurement $(\mathrm{ng} / \mathrm{ml})$

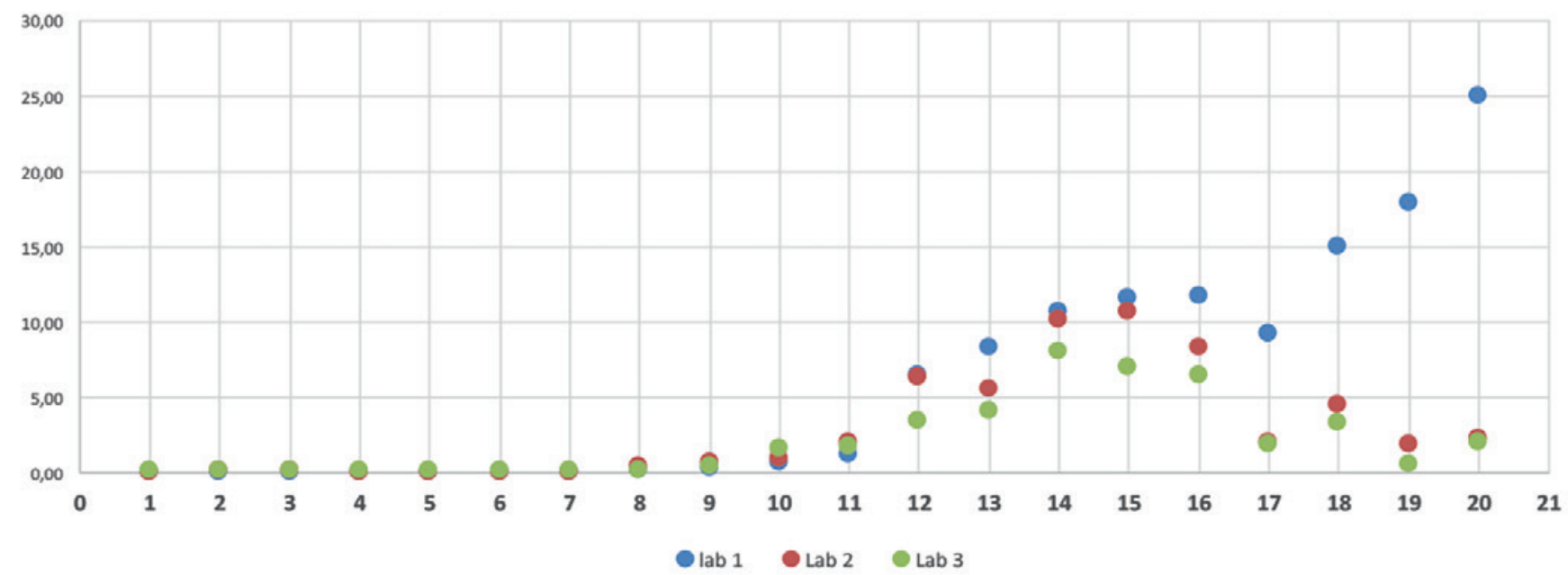

Figure 4. Differences in serum progestogen measurements in the second half of gestation, depending on laboratory. Serum progestagen measurements in $\mathbf{2 1}$ mare samples performed in three different commercial laboratories in Flanders. Mares 1-16 are normal cycling mares; mares 17-21 are in the second half of an uncompromised pregnancy. A clear discrepancy can be noted between the results. Only lab 1 seems to be able to determine other progestagens than progesterone in the second half of pregnancy in the mare.

though elevated levels beyond day 305 of gestation cannot be differentiated from the normal physiological rise in progestin levels in the last three weeks of uncompromised gestations (Morris et al., 2007).

In a clinical setting, mares can be monitored by sampling three times a week, or by taking four samples at 48-hour intervals in the acute phase and biweekly thereafter to assess the effectiveness of therapy (Morris et al., 2007; Macpherson and Bailey, 2008a). When treatment is successful, the CTUP measurements diminish rapidly, and the progestin levels and clinical symptoms tend to normalize.

Besides progestins, estradiol is sometimes used as a marker for feto-placental compromise. Estrogen precursors (C19) are secreted by the fetal gonads. In contrast to what is seen in the fetal adrenal glands, fetal gonads do not respond to stress and as a result, the estrogen levels only change in severely compromised, almost ill-fated pregnancies (Ousey, 2006). Concentrations above $1000 \mathrm{ng} / \mathrm{ml}$ between 150 days and 280 days are assumed to be normal; while concentrations less than $500 \mathrm{ng} / \mathrm{ml}$ have been associated with severely compromised or dead foals (LeBlanc, 2010).

Relaxin, a polypeptide that is mainly produced by the placenta during pregnancy (Stewart et al., 1982; Klonisch et al., 1995; 2000), has been shown to promote uterine growth (Hall et al., 1990; Hall et al., 1992), inhibit myometrial contractions (Watts et al., 1988) and loosen the tissues of the caudal genital tract in preparation for parturition in many species $(\mathrm{Grahm}$ and Darcy, 1952; Steinitz et al., 1959; Kertiles and Anderson, 1979; MacLennan et al., 1980; O’Day et al., 1989; Ryan et al., 1999). Alterations in relaxin blood profiles are seen in women with impending miscarriage (Witt et al., 1990; Stewart et al., 1993) and in dogs suffering early embryonic loss (GunzelApel et al., 2008).

In mares, relaxin serum levels are high (varying from $45.0-85.0 \mathrm{ng} / \mathrm{ml}$ ) at end of gestation and increase during labor. Plasma relaxin declines markedly in mares with problematic pregnancies (Ryan et al. 1999). Previous work, however, has shown that relaxin concentrations can vary and are different between breeds and are thus of limited value as a placentitis marker in the mare (Klonisch et al., 1995; Ryan et al., 2009). Nevertheless, the one (and only) proven use of plasma relaxin in mares is its use as a non-invasive marker of placental function, to be considered in addition to and as a complement to other diagnostic findings (Ryan et al., 1999).

Prostaglandins are released locally by the uteroplacental tissues and are rapidly metabolized. Therefore, they cannot be used for diagnosis of placentitis (LeBlanc, 2010).

Other serological markers for diagnosing placetitis are far from specific. Acute phase proteins (haptoglobulin and serum amyloid A (SAA)) will rise as a response to the infection, with SAA showing a marked increase. The finding that SAA increases in response to placentitis gives new insights into the disease process. This increased concentration of SAA can only be explained in terms of the contribution of the endometrium to this rise or, although always regarded as a local process, in terms of its systemic involvement in the pathogenesis of placentitis (Canisso et al., 2014). The fibrinogen levels and the white blood cell count do not change post inoculation (Canisso et al., 2014). Other serum markers, such as alpha-fetoprotein (AFP), are still under research (Canisso et al., 2015). 


\section{TREATMENT}

Treatment should aim at reducing the spread of the germs, eliminating the inflammation, reducing cytokine signalling, preventing prostaglandin synthesis and thus preventing uterine contractions and preterm delivery of the fetus (LeBlanc, 2010; Lyle, 2014). To obtain these targets, a combination of antibiotics and anti-inflammatory drugs, whether or not supplemented with hormones, are most currently given as therapy.

Parturition induction in order to obtain better chances for the foal's survival is not an option (Jeffcott and Rossdale, 1977; Rossdale and Silver, 1982; Leadon et al., 1986). The foal and its chances of survival benefit from any delay of preterm parturition. When a premature expulsion can be avoided, the maturation of the foal in a chronic stress situation is accelerated. This increases its chances of survival by a significant degree (Rossdale et al., 1991; LeBlanc et al., 2004; Ousey, 2006; Bailey et al., 2007; Christiansen et al., 2009). The artificial acceleration of foal maturation with the aid of cortisone (e.g. dexamethasone I.M., at a dose rate of $100 \mathrm{mg}$ q 24 hours for three consecutive days) is sometimes considered, although it has variable effects, depending on the product used and the degree of HPA activity (Alm et al., 1975; Jeffcott and Rossdale, 1977; Christiansen et al., 2005), and it is not without risks due to the side effects of the corticosteroids (Rossdale et al., 1992; Ousey et al., 2006).

In addition to their effects on the fetal HPA, corticosteroids also have an immunosuppressive effect that can affect prostaglandin production (Gravett et al., 2000). Even so, PG synthetase inhibitors (e.g. meclofenamic acid) (Silver et al., 1979) and cyclooxygenase inhibitors (e.g. flunixin meglumine, at a dose rate of $1.1 \mathrm{mg} / \mathrm{kg}$ b.i.d.) reduce prostaglandin 2 alpha concentrations, without inhibiting the oxytocin induced delivery a term (Ousey, 2006).

The most commonly used antimicrobial to treat placentitis is trimethoprim sulfamethoxazole (TPS), which has good oral bioavailability in horses (Zent, 1999), although its activity may be reduced in the presence of pus, and some strains of Streptococci are resistant to it (Peyrou et al., 2003). Therapies with a combination of TPS and pentoxifylline (Pf) prolong gestation but do not prevent stillbirth (Graczyk et al., 2006). Penicillin and gentamycin have also been used, though their concentrations in the allantoic fluid reach only about $80 \%$ of the serum concentrations, whereas TPS and Pf reach serum concentrations in the allantoic fluids (Murchie et al., 2006; Rebello et al., 2006). In affected mares, the gentamycin concentrations are reduced below the minimal inhibitory concentrations (MIC) of gramm-negative bacteria, whilst the clearance of penicillin $\mathrm{G}$ from the allantoic cavity is delayed, resulting in concentrations that are possibly toxic for the fetus (Murchie et al., 2006). Specific posology and dosages of therapeutics in cases of placentitis are reviewed in LeBlanc et al. (2010) (Table 1).

The administration of pentoxifylline (Pf) is based on its anti-inflammatory properties by reducing the amount of cytokines (TNF $\alpha$ and IL-1) (Lauterbach et al., 1996; Baskett et al., 1997, Ousey et al., 2010). Although previously presumed effective, even a double dose of Pf (a ratio of $17 \mathrm{mg} / \mathrm{kg}$ BID) does not alter the arterial blood flow (Bailey et al., 2012). In earlier tri-

Table 1. Dosage and posology of therapeutics (adapted from: LeBlanc, 2010). The AMCRA recommendations. Ease of use and cost price, which depend on the pharmaceutical formulation and vary from country to country, and as such most appropriate for the situation in Belgium. The withdrawal times and legal implications of administration, which may differ between countries and change over time, should be consulted up front.

\begin{tabular}{|c|c|c|c|c|c|c|c|c|}
\hline & & $\begin{array}{l}\text { AMCRA } \\
\text { code }\end{array}$ & $\begin{array}{l}\text { Withdrawal } \\
\text { (FP) }\end{array}$ & Dose & $\begin{array}{l}\text { Poso- } \\
\text { logy }\end{array}$ & $\begin{array}{l}\text { Appli- } \\
\text { cation }\end{array}$ & $\begin{array}{l}\text { Ease of } \\
\text { use }\end{array}$ & $\begin{array}{l}\text { Cost } \\
\text { price }\end{array}$ \\
\hline \multirow[t]{4}{*}{ Antimicrobial } & Trimethoprim sulpha & 1 & $14 \mathrm{~d}$ & $15-30 \mathrm{mg} / \mathrm{kg}$ & $\mathrm{q} 12 \mathrm{~h}$ & p.o. & $*$ & $*$ \\
\hline & Potassium penicillin $\mathrm{G}$ & & $6 \mathrm{mth}$ & $22000 \mathrm{IU} / \mathrm{kg}$ & $\mathrm{q} 6 \mathrm{~h}$ & i.v. & $* * *$ & $* *$ \\
\hline & Gentamycin & 2 & $6 \mathrm{mth}$ & $6.6 \mathrm{mg} / \mathrm{kg}$ & $\mathrm{q} 24 \mathrm{~h}$ & i.v. & $* *$ & $* *$ \\
\hline & Ceftiofur & 3 & $6 \mathrm{mth}$ & $20 \mathrm{mg} / \mathrm{kg}$ & $\mathrm{q} 12 \mathrm{~h}$ & i.v./i.m. & $* *$ & $* * *$ \\
\hline \multirow[t]{2}{*}{ Tocolytic } & Altrenogest & & $9 d$ & $0.088 \mathrm{mg} / \mathrm{kg}$ & $\mathrm{q} 24 \mathrm{~h}$ & p.o. & $*$ & $*$ \\
\hline & Isoxsuprine & & & $0.4-0.6 \mathrm{mg} / \mathrm{kg}$ & $\mathrm{q} 24 \mathrm{~h}$ & p.o. & $*$ & \\
\hline \multirow[t]{4}{*}{ Anti-inflammatory } & Flunixin meglumine & & $7-10 \mathrm{~d}$ & $1.1 \mathrm{mg} / \mathrm{kg}$ & q $12-24 h$ & i.v./p.o. & $*$ & $* *$ \\
\hline & Phenylbutazone & & NFP & $2.2 \mathrm{mg} / \mathrm{kg}$ & q $12-24 h$ & p.o. & $*$ & $*$ \\
\hline & Pentoxifylline & & $6 \mathrm{mth}+$ pass & $8.5 \mathrm{mg} / \mathrm{kg}$ & $\mathrm{q} 12 \mathrm{~h}$ & p.o. & $*$ & $*$ \\
\hline & Acetylsalicyl zuur & & & $50 \mathrm{mg} / \mathrm{kg}$ & $\mathrm{q} 12 \mathrm{~h}$ & p.o. & $*$ & $*$ \\
\hline $\begin{array}{l}\text { Anti-inflammatory } \\
+ \text { stimulation fetal } \\
\text { maturation }\end{array}$ & Dexamethasone & & $8 \mathrm{~d}$ & $\begin{array}{l}40-35-25 \mathrm{mg} \\
\text { (decrease dose } \\
\text { every } 48 \mathrm{~h} \text { ) }\end{array}$ & $\mathrm{q} 24 \mathrm{~h}$ & i.v. & $*$ & $*$ \\
\hline
\end{tabular}

*: low cost / easy to use, ***: high cost / more difficult to use

$\mathrm{FP}=$ food producing/ Non-FP 
als, when given for a prolonged period of time, Pf did increase uterine blood flow, thus ameliorating oxygen transport (Bacher et al., 1997; 2005). By altering the flow characteristics of equine erythrocytes in vitro (Weis et al., 1994), Pf might help in bacterial clearance, thus impeding colonization, as shown in rabbits (Heller et al., 1999). Normal therapies use a dosage of $8-10 \mathrm{mg} / \mathrm{kg}$ q 12 hours, with maximal concentrations being reached in about one hour post administration (Liska et al., 2006). For similar empirical reasons, acetylsalicylacid $(150 \mathrm{mg} / \mathrm{kg}$, p.o., b.i.d.) is sometimes advocated.

Besides antimicrobials and anti-inflammatory medication, several drugs that act to impede any preterm contraction of the uterus ( $\beta$-sympathomimetics, prostaglandin synthesis inhibitors, calcium channel blockers, oxytocin antagonists) have been tested in humans (Lamont 2005), though none of them were able to prolong the pregnancy or improve the prognosis when used alone. In mares, the anti-prostaglandin effect of progesterone (analogues) prevents prostaglandin induced abortion in most cases in the first trimester of gestation (Daels et al., 1996). Apparently, the upregulation of oxytocin and prostaglandin receptors is inhibited at that stage by the administration of progesterone, and without these receptors and the formation of gap junctions between the myometrial cells, uterine contraction cannot happen (Garfield, 1980). The specific action and efficacy of progesterone supplementation as a way to prevent abortion in late gestation still remain equivocal (Ousey, 2006). Since the plasma progesterone concentrations are increased in most of these placentitis mares, supplementation is questionable. Some authors believe that it might be contraindicated, since a supplement of P4

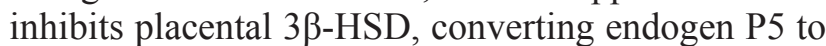
P4 (Chavatte et al., 1995; Schutzer et al. 1996). A total blockage of $3 \beta$-HSD leads to parturition in most animals, but not in the mare (Fowden et al. 1987; Silver and Fowden,1988; Chavatte et al. 1997). Most likely, other progestogens play a more determining role in preventing preterm birth in the mare (Ousey, 2006). Nevertheless, to date, progesterone supplementation remains a part of the standard therapy protocol in placentitis cases. Commonly, a dosage of altrenogest of $0.088 \mathrm{mg} / \mathrm{kg}$ bwt q 24 hour per os is used.

When $\beta$-sympathomimetics such as clenbuterol are used in the mare, uterine relaxation is seen within minutes, and lasts for up to two hours (Card and Wood, 1995). However, no significant difference in gestation length has been seen (Palmer et al., 2002). Moreover, treated mares tend to foal earlier than controls, as clenbuterol may induce cervical relaxation and subsequent parturition; hence, clenbuterol has only limited use in placentitis in mares (Palmer et al., 2002).

The duration of placentitis therapy (antibiotics, NSAID's, altrenogest) is still under debate. Cures of 10-14 days of antibiotics with seven days of NSAID's have been advised by some, while others advise to treat until delivery of the foal (Zent et al., 1999; Le Blanc, 2010). Prolonged antibiotic and NSAID therapy may result in gastrointestinal side effects and antibiotic resistance (LeBlanc, 2009). Protracted progestin therapy up to the time of delivery may lead to prolonged stage 2 and subsequent neonatal complications (Neuhauser et al., 2008). It is therefore advisable to stop progesterone therapy at 320 days of gestation (LeBlanc, 2010). To complicate the discussion even more, in most placentitis mares, even after a prolonged antibiotic therapy, uterine swabs post foaling still show bacterial growth (Bailey et al., 2010).

Early and aggressive combination therapy is necessary until clinical signs disappear (Rebello et al. 2006, Christiansen et al., 2009; LeBlanc, 2009), associated with regularly checking the effect of the therapy by monitoring the viability of the foal (Macpherson and Bailey, 2008a; LeBlanc, 2010).

Mares that suffer from placentitis should be placed under close surveillance to enable assisted delivery of the foal, since the thickened placenta prevent in most cases a timely rupture of the cervical star leading to a so called 'red bag' delivery. After foaling or abortion, they should be checked for endometrial infection for the purpose of selecting the most appropriate therapy. When this check-up for infection is delayed, the samples will always reveal a mixed infection (Macpherson and Bailey, 2008b; Bailey et al., 2010). In most cases, three consecutive days of uterine flushes in combination with NSAID's and a week of antimicrobial therapy clear the infected post-partum uterus.

Logically, after placental expulsion, a thorough examination of the placenta is essential. Bacterial sampling will not be of any use, but a visual check-up for gross lesions (especially at the caudal chorionic part and cervical star region) and histological examination of the region of interest can help to diagnose placentitis (Mays et al., 2002). In the event of ascending placentitis, a thickened, discolored, edematous or even ulcerated chorioallantois is present at the level of the cervical star (Platt, 1975b; Hong et al., 1993; Mays et al., 2002) (Figure 1). Gross lesions at macroscopic inspection are not specific, as they may be absent in the event of placentitis or be caused by other diseases, as in cases of cervical pool necrosis (Löf et al., 2014). Furthermore, the ultrasonographic feature of a thickened placenta is not correlated with the total weight of the placenta after expulsion (Löf et al., 2014); however, a heavier placenta may be caused by inflammation and should be sampled for histology to exclude placentitis.

\section{PROGNOSIS}

As mentioned above, the mare's health status is not affected unless severe complications occur. The prognosis for the fetus is acceptable when early, aggressive therapy can be initiated; however, in a first- 
line approach, this is quite difficult due to the insidious course and discrete signs of placentitis (Bailey et al., 2010).

In any case, longer intervals from parturition to subsequent pregnancy (with on average one month extra) have been noted in affected Thoroughbred mares compared to normal Thoroughbred mares (Hughes et al., 2014).

Foals born from affected mares should be checked meticulously for signs of pre- or dysmaturity and septicemia. The description of the whole scale of controls and therapeutic considerations relating to the neonate is beyond the scope of this paper. In any case, measurement of the foal serum cortisol level in addition to the blood analysis, with specific attention to the neutrophil/lymphocyte ratio, should be part of the first screening. The foals should be supervised closely until there is certainty - and even more so in the presence of suspected signs (clinical signs during pregnancy and/or placental gross lesions). In addition to strictly monitoring the colostrum intake and the essential viability parameters, antibiotic therapy should also be started unless it is deemed unnecessary.

Foals born out of chronically infected and inflamed placentas, in association with high sero-progestin levels in the dam, have some (premature) degree of fetal HPA activity and increased cortisol levels, which promote their survival (Ousey, 2006). However, elevated levels of glucocorticoids, together with the limited nutrient and blood supply due to the reduced placental bloodflow, cause a reduction in fetal body weight and may be associated with poor skeletal development and limb deformities of the neonate (Ousey, 2006). Surviving foals may need expensive intensive care and may possibly never reach the expected levels of athletic performance. In the US, the costs of clinical care for such foals born out of such compromised gestations have been estimated to run between $\$ 2,000$ and over $\$ 10,000$ (Barr, 2005). This is a consideration that should be communicated to the owner before initiating such therapy (LeBlanc, 2010). In any case, pre- and postnatal epigenetic conditions determine the possible athletic capacities of the offspring in its later life (Axon et al., 1999; Hughes et al., 2014).

An examination of the Timeform ratings of threeyear-old race horses has revealed that only very few of those born with low birth weight reached standard ratings, regardless of their origin (Platt, 1975b; 1978). The fact that Hughes et al. (2014) could not see any differences in their retrospective study looking at the performance of yearlings and two-year-olds born out of compromised pregnancies versus controls born out of uneventful pregnancies, must be viewed in light of the fact that the pre-test criteria included mainly subclinical cases of placentitis and (of course) the fact that only the surviving foals were taken into account.

Finally, in addition to mares that show clinical signs of ascending placentitis, also mares that have suffered from placentitis in a previous pregnancy should be monitored from the seventh month of gestation onwards. Since the pathogenesis usually involves an aberrant functionality of the physical barriers guarding the sterility in utero, when this dysfunctionality remains unresolved (or is unresolvable), the infection-inflammation may emerge in any of the subsequent pregnancies.

\section{CONCLUSION}

Recognizing an ascending infection of the placenta in the pregnant mare can be difficult since the symptoms may be discrete, and/or they may be exhibited only in a late stage of the disease. Nevertheless, the process of elucidating the entire pathological pathway may result in the development of other diagnostic and therapeutic tools. So far, the evaluation of the progestogen profiles of suspected mares, in association with transrectal ultrasound evaluation of the placenta, seems to enable the diagnosis of most placentitis cases adequately (Morris et al., 2007). However, initiating early and aggressive combination treatment (antibiotics, anti-inflammatory drugs and altrenogest) can be difficult and, as a result, the prognosis remains guarded. Foals born out of a compromised gestation should be systematically and rigorously monitored for pre- or dysmaturity and septicemia. Affected mares should be examined in order to eliminate any underlying causes. Any mare at risk needs to be examined frequently during the subsequent gestation, from the seventh month onward, to ensure timely diagnosis should placentitis reoccur.

\section{ACKNOWLEDGEMENTS}

The authors would like to thank Jeroen Hoekstra, Gerwin Buis (BigPixel(C) and Fleur Solleveld for their valuable contributions, figures and cartoons in this publication.

\section{LITERATURE}

AMCRA formularium. Kenniscentrum voor antibioticagebruik en -resistentie bij dieren in België. Website: http:// www.amcra.be/nl/formularia/formularia, consulted on 08/12/2016

Acland H.M. (1993). Abortion. In: McKinnon A.O., Voss J.L. (editors). Equine Reproduction. Lea \& Febiger, Philadelphia, pp. 554-561.

Alm C.C., Sullivan J.J., First N.L.(1975). The effect of a corticosteroid (dexamethasone), progesterone, oestrogen and prostaglandin F2alpha on gestation length in normal and ovariectomized mares. Journal of Reproduction and Fertilility Supplement 23, 637-640.

Axon J., Palmer J., Wilkins P. (1999). Short- and long-term 
athletic outcome of neonatal intensive care unit survivors. In: Proceedings American Association Equine Practitioners. Albuquerque, New Mexico, dec 5-8 th $45,224-225$.

Bacher A., Eggensperger E., Koppensteiner R., Mayer N., Klimscha W. (2005). Pentoxifylline attenuates the increase in whole blood viscosity after transfusion. Acta Anaesthesiologica Scandinavica 49, 41-46.

Bacher A., Mayer N., Klimscha W., Oismuller C., Steltzer H., Hammerle A. (1997). Effects of pentoxifylline on hemodynamics and oxygenation in septic and non septic patients. Critical Care Medicine 25, 795-800.

Bailey C.S., Macpherson M.L., Graczyk J., Pozor M.A., Troedsson M.H.T., LeBlanc M.M., Vickroy T.W. (2007). Treatment efficacy of trimethoprim sulfamethoxazole, pentoxifylline, and altrenogest in equine placentitis. In: Proceedings of the American Association of Equine Practitioners. Orlando, Florida, Vol. 53 Orlando, FL, pp. 339-340.

Bailey C.S., Macpherson M.L., Pozor M.A., Troedsson M.H.T., Benson S., Giguere S., Sanchez L.C., LeBlanc M.M., Vickroy T.W. (2010). Treatment efficacy of trimethoprim sulfamethoxazole, pentoxifylline, and altrenogest in experimentally induced equine placentitis. Theriogenology 74, 402-412.

Bailey C.S., Sper R.B., Schewmaker J.L., Buchanan C.N., Beachler T.M., Pozor M.A., Whitacre M.D. (2012). Uterine artery blood flow remains unchanged in pregnanct mares in response to short-term administration of pentoxifylline. Theriogenology 77, 430-436.

Barr B.S. (2005). The outcome of foals born to mares treated for placentitis. In: Uterine Infections in Mares and Women: a Comparative Study II. England: R\&W Communications. Havemeyer Foundation Monograph Series No. 19, 49-50.

Baskett A., Barton M.H., Norton N., Anders B., Moore J.N. (1997). Effect of pentoxifylline, flunixine meglumine, and their combination on a model of endotoxemia in horses. American Journal Veterinary Research 58, 12911299.

Brendemuehl J.P., Williams M.A., Boosinger T.R., Ruffin C. (1995). Plasma progestogen, tri-iodothyronine, and cortisol concentrations in postdate gestation foals exposed in utero to the tall fescue endophyte acremonium coenophalium. Biology of Reproduction Monograph 1, 53-59.

Bucca S. (2006). Diagnosis of the compromised equine pregnancy. Veterinary Clinics of North America Equine Practice 22, 749-761.

Bucca S., Fogarty U., Collines A., Small V. (2005). Assessmnet of feto-placental well-being in the mare from mid-gestation to term: transrectal and transabdominal ultrasonographic features. Theriogenology 64, 542-557.

Bucca S., Fogarthy U. (2011). Ultrasonographic cervical parameters throughout gestation in the mare. In: Proceedings of the $57^{\text {th }}$ Annual Convention of the AAEP. Nov 17-20 $0^{\text {th }}$ San Antonio, Texas 57, 235-241.

Canisso I.F., Ball B.A., Scoggin K.E., Squires E.L., Williams N.M., Troedsson M.H. (2015). Alpha-fetoprotein is present in the fetal fluids and is increased in plasma of mares with experimentally induced ascending placentitis. Animal Reproduction Science 154, 48-55.

Canisso I.F., Ball B.A., Cray C., Williams N.M., Scoggin K.E., Davolli G.D., Squires E.L., Troedsson M.H. (2014). Serum amyloid A and haptoglobin concentrations are in- creased in plasma of mares with ascending placentitis in the absence of changes in peripheral leucocyte counts or fibrinogen concentration. American Journal of Reproductive Immunology 72, 376-385.

Card C.E., Wood M.R. (1995). Effects of acute administration of clenbuterol on uterine tone and equine fetal and maternal heart rates. Biology of Reproduction Monograph 1, 7-11.

Challis J.R.G., Matthews S.G., Gibb W., Lye S.G. (2000). Endocrine and paracrine regulation of birth at term ad preterm. Endocrine Reviews 21, 515-550.

Chavatte P., Holtan D., Ousey J.C., Rossdale P.D. (1997). Biosynthesis and possible biological roles of prostagens during equine pregnancy and in the newborn foal. Equine Veterinary Journal Supplement 24, 89-95.

Chavatte P.M., Rossdale P.D., Tait A.D. (1995). Modulation of 3 beta-hydroxysteroid dehydrogenase (3 betaHSD) activity in the equine placenta by pregnenolone and progesterone metabolites. Equine Veterinary Journal 27(5), 342-347.

Chirstiansen B.W., Crouch J., Hopper R., Moulton K., Le Blanc M.M., Ryan P.L. (2009). Experimentally induced placentitis in late gestation mares with Streptococcus equi zooepidemicus: therapeutic prevention of preterm birth. Clinical Theriogenology Journal 1, 239.

Christiansen D., Olsen G., Smith J., Hopper R., LeBlanc M.M., Ryan P. (2005). The use of betamethasone to advance fetal maturation in the equine. Havemeyer Foundation Monograph Series 19, 19-20.

Cummins C., Carrington S., Fitzpatrick, E. Duggan V. (2008). Ascending placentitis in the mare: a review. Irish Veterinary Journal 61, 307-313.

Daels P.F., Besognet B., Hansen B., Mohammed H., Odensvik K., Kindagl H. (1996). Effect of progesterone on prostaglandin F2 alpha secretion and outcome of pregnancy during cloprostenol-induced abortion in mares. American Journal Veterinary Research 57, 1331-1337.

Dudley D.J. (1997). Preterm labor: An intrauterine inflammatory response syndrome? Journal of Reproductive Immunology 36, 93-109.

Fowden A.L., Silver M. (1987). Effect of inhibiting 3 $\beta$-hydroxysteroid dehydrogenase on plasma progesterone and other steroids in the pregnant mare near term. Journal of Reproduction and Fertility Suppl 35, 539-545.

Garfield R.E., Kannan M.S., Daniel M.E. (1980). Gap junction formation in the myometrium: control by estrogens, porgesterone and prostaglandins. American Journal of Physiology 238, 81-89.

Gibb W, Challis J.R. (2002). Mechanisms of term and preterm birth. Journal of Obstetrics and Gynaecology Canada 24, 874-883.

Giles R.C., Donahue J.M., Hong C.B., Tuttle P.A., PetritesMurphy M.B., Poonacha K.B., Roberts A.W., Tramontin R.R., Smith B., Swerczek T.W. (1993). Causes of abortion, stillbirth, and perinatal death in horses: 3.527 cases (1986-1991). Journal of the American Veterinary Medical Association 203, 1170-1175.

Govaere J., Hoogewijs M., De Schauwer C., Van Zeveren A., Smits K., Cornillie P., de Kruif A. (2009). An abortion of monozygotic twins in a warmblood mare. Reproduction in Domestic Animals 44, 852-854.

Gunzel-Apel A.R., Zabel S., Bunk C.F. Hoppen H.-O., Dieleman S.J., Einspanier A. (2008). Concentrations on progesterone, prolactin and relaxin in the luetal phase and 
pregnancy in normal and short-cycling German Shepherd dog. Tierärztliche Praxis Kleintiere 3, 205-209.

Graczyk J., Macpherson M.L., Pozor M.A., Troedsson M.H.T., Eichelberger A.C., LeBlanc M.M. et al. (2006) Treatment efficacy of trimethoprim sulfamethoxazole and pentoxifylline in equine placentitis. Animal Reproduction Science 94, 434-435.

Grahm E.F., Darcy A.E. (1952). The effect of relaxin and mechanical dilation on the bovine cervix. Journal of Dairy Science 36, 772-777.

Gravett M., Hitti J., Hess D., Eschenbach D. (2000). Intrauterine infection and preterm delivery: evidence for activation of the fetal hypothalamic-pituitary-adrenal axis. American Journal of Obstetrics \& Gynecology 182, 1404-1413.

Hall J.A., Cantley T.C., Day B.N., Anthony R.V. (1990). Uterotropic actions of relaxin in prepubertal gilts. Biology of Reproduction 42, 769-74.

Hall J.A., Cantley T.C., Galvin J.M., Day B.N., Anthony R.V. (1992). Influence of ovarian steroids on relaxin-induced uterine growth in ovariectomized gilts. Endocrinology 130, 3159-3166.

Handler J., Konigshofer M., Kindahl H., Schams D., Aurich C.(2003). Secretion aptterns of oxytocin and PGF2 alpha-metabolite in response to cervical dilatation in cyclic mares. Theriogenology 59, 1381-1391.

Heller S., Weber K., Heller A., Urbaschek R., Koch T. (1999). Pentoxifylline improves bacterial clearance during haemorrhage and endotoxemia. Critical Care Medicine 27, 756-763.

Hinrichs K., Cummings M.R., Sertich P.L., Kenney R.M. (1988). Clinical significance of aerobic bacterial flora of the uterus, vagina, vestibule and clitoral fossa of clinical normal mares. Journal of the American Veterinary Medical Association 193, 72-75.

Hong C.B., Donahue J.M., Giles R.C.Jr., Petrites-Murphy M.B., Poonchata K.B., Roberts A.W., Smith B.J., Tramontin R.R., Tuttle P.A., Swerczek T.W. (1993). Etiology and pathology of equine placentitis. Journal of Veterinary Diagnostic Investigation 5, 56-63.

Hong C.B., Donahue J.M., Giles R.C.Jr., Petrites-Murphy M.B., Poonchata K.B., Roberts A.W., Smith B.J., Tramontin R.R., Tuttle P.A., Swerczek T.W. (1993). Equine abortion and stillbirth in central Kentucky during 1988 and 1989 foaling seasons. Journal of Veterinary Diagnostic Investigation 5, 560-566.

Hudson N.P.H., Prince D.R., Mayhew I.G., Watson E.D. (2005). Investigation and management of a cluster of cases of equine retained fetal membranes in Highland ponies. Veterinary Record 157, 85-89.

Hughes S.M.S., Stowe C.J., Troedsson M.H.T., Ball B.A., Squires E.L. (2014). The athletic performance of Thoroughbred racehorses out of mares with suspected placentitis during gestation. Journal of Equine Veterinary Science 34, 514-519.

Jeffcott L.B., Rossdale P.D. (1977). A critical review of current methods for induction of parturition in the mare. Equine Veterinary Journal 9, 208-215.

Kelleman A.A., Luznar S.L., Lester G.D., Paccamonti D.L., LeBlanc M.M. (2002). Evaluation of transrectal ultrasonographic combined thickness of the uterus and placenta (CTUP) in a model of induced ascending placentitis in late gestation in the pony mare. Theriogeno$\log y 58,845-848$.
Keelan J.A., Sato T., Mitchell M.D. (1997). Interleukin (IL)-6 and IL-8 production by human amnion: regulation by cytokines, growth factors, glucocorticoids, phorbol esters, and bacterial lipopolysaccharide. Biology of Reproduction 57, 1438-1444.

Kertiles L.P., Anderson L.L. (1979). Effect of relaxin on cervical dilation, parturition and lactation in the pig. Biology of Reproduction 21, 57-68.

Klonisch T., Hombach-Klonisch S. (2000). Review: relaxin expressed at the feto-maternal interface. Reproduction in Domestic Animals 35, 149-152.

Klonisch T., Ryan P.L., Yamashiro S., Porter D.G. (1995). Partial complementary deoxyribonucleic acid cloning of equine relaxin messenger ribonucleic acid, and its localisation within the equine placenta. Biology of Reproduction 52, 1307-1315.

Laugier C., Foucher N., Sevin C., Leon A., Tappest J. (2011). A 24-year retrospective study of equine abortion in Normandy (France). Journal of Equine Veterinary Science 31, 116-123.

Lauterbach R., Zembala M. (1996). Pentoxifylline reduces plasma tumor necrosis factor-alpha concentration in premature infants with sepsis. European Journal of Pediatrics 155, 404-409.

Lamont R.F. (2005). Can antibiotics prevent preterm birth - the pro and con debate. International Journal of $\mathrm{Ob}$ stetrics and Gynaecology 112, 67-73.

Leadon D.P., Jeffcott L.B., Rossdale P.D. (1986). Behavior and viability of the premature neonatal foal after induced parturition. American Journal Veterinary Research 47, 1870-1873.

LeBlanc M.M. (2010). Ascending placentitis in the mare: an update. Reproduction in Domestic Animals 45, 28-34.

LeBlanc M.M. (2009). The current status of antibiotic use in equine reproduction. Equine Veterinary Education 21, 156-167.

LeBlanc M.M., Giguerre S., Brauer K., Paccamonti D.L., Horohov D.W., Lester D.G., O’Donnel L.J., Sheerin B.R., Pablo L., Rodgerson D.H. (2002). Premature delivery in ascending placentitis is associated with increased expression of placental cytokines and allantoic fluid prostaglandins E2 and F2alpha. Theriogenology 58, 841-844.

LeBlanc M.M., Macpherson M.L., Sheerin P.C. (2004). Ascending placentitis: what we know about pathophysiology, diagnosis and treatment. In: Proceedings of the American Association of Equine Practitioners vol 50, Denver C.O., pp. 127-143.

Liska D.A., Akucewich L.H., Marsella R., Maxwell L.K., Barbara J.E., Cole C.A. (2006). Pharmacokinetics of pentoxifylline and its 5-hydroxyhexyl metabolite after oral and intravenous administration of pentoxifylline to healthy adult horses. American Journal Veterinary Research 67, 1621-1627.

Löf H.K., Gregory J.W., Neves A.P., Jobim M.I.M., Gregory R.M., Mattos R.C. (2014). Combined thickness of the uterus and placenta (CTUP) as indicator of placentitis in Thoroughbred mares. Pferdeheilkunde 30, 37-41.

Lyle S.K. (2014). Immunology of infective preterm delivery in the mare. Equine Veterinary Journal DOI: 10.1111/ evj. 12243

Lyle S.K., Gentry L.R., Horohov D.W., Johnson J.R., Eilts B.E., Godke R.A., Paccamonti D.L. (2009). Preliminiary evidence of fetal hypothalamic-pituitary-adrenal axis activation in an experimental model of infective preterm 
delivery in the mare. Clinical Theriogenology Journal 1, 238.

MacLennan A.H., Green R.C., Bryant-Greenwood G., Greenwood F.C., Semark R.F. (1980). Ripening of the human cervix and induction of labor with purified porcine relaxin. Lancet 1, 220-223.

Macpherson L.M. (2006). Diagnosis and treatment of equine placentitis. Veterinary Clinics Equine Practice 22, 763-776.

Macpherson M.L., Bailey C.S.A. (2008). Clinical approach to managing the mare with placentitis. Theriogenology 70, 435-440.

Macpherson M.L., Bailey C.S. (2008). Treating the mare with placentitis clinical approach. Journal of Equine Veterinary Science 28, 703-708.

Mays M.B.C., LeBlanc M.M., Paccamonti D. (2002). Route of fetal infection in a model of ascending placentitis. Theriogenology 58, 791-792.

McGlothlin J.A., Lester G.D., Hansen P.J., Thomas M., Pablo L., Hawkins D.L., LeBlanc M.M. (2004). Alteration in uterine contractility in mares with experimentally induced placentitis. Reproduction 127, 57-66.

Merkt H. (1985). Trächtigkeitverluste beim Pferd und die Möglichkeiten ihren Reduziering. Tierärztliche Umschau 40, 428-435.

Morris S., Kelleman A.A., Stawicki R.J., Hansen P.J., Sheerin P.C., Sheerin B.R., Paccamonti D.L., LeBlanc M.M. (2007). Transrectal ultrasonography and plasma progestin profiles identifies feto-placental compromise in mares with experimentally induced placentitis. Theriogenology 67, 681-691.

Murchie T.A., Macpherson M.L., LeBlanc M.M., Luznar S., Vickroy T.W. (2006). Continuus monitoring of penicillin $\mathrm{G}$ and gentamicin in allantoic fluid of pregnant pony mares by in vivo microdialysis. Equine Veterinary Journal 38, 520-525.

Neuhauser S., Palm F., Ambuehl F., Aurich C. (2008). Effects of altrenogest treatment of mares in late pregnancy on parturition and on neonatal viability of their foals. Experimental and Clinical Endocrinology \& Diabetes 116, 423-428.

O’Day M.B., Winn R.J., Easter R.A., Dzuik P.J., Sherwood O.D. (1989). Hormonal control of the cervix in pregnant gilts III. Relaxin's influence on cervical biochemical properties in ovariectomized hormone treated pregnant gilts. Endocrinology 129, 1967-1976.

Ousey J.C. (2004). Peripartal endocrinology in the mare and foetus. Reproduction in Domestic Animals 39, 222-235.

Ousey J.C. (2006). Hormone profiles and treatments in the late pregnant mare. Veterinary Clinics of North America Equine Practice 22, 727-747.

Ousey J.C., Dudan F., Rossdale P.D. (1984). Preliminar studies of mammary secretions I the mare to assess fetal readiness for birth. Equine Veterinary Journal 16, 259-263.

Ousey J.C., Forhead A.J., Rossdale P.D., Grainger L., Houghton E., Fowden A.L. (2003). Ontogeny of uteroplacental progestogen production in pregnant mares during the second half of gestation. Biology of Reproduction 69, 540-548.

Ousey J.C., Houghton E., Grainger L., Rossdale P.D., Fowden A.L. (2005). Prostagen profiles during the last trimester of gestation in Thoroughbred mares with abnormal or compromised pregnancies. Theriogenology $63,1844-1856$.
Ousey J.C., Koelling M., Allen W.R. (2006). The effects of maternal dexamethasone treatment on gestation length and foal maturation in Thoroughbred mares. Animal Reproduction Science 94, 436-438.

Ousey J.C., Koelling M., Willis D., Allen W.R. (2010). Effects of pentoxifylline on uterine blood flow, and placenta land fetal development in young and aged mares with endometriosis. Animal Reproduction Science 121, 343-344.

Palmer E., Chavette-Palmer P., Duchamp G. (2002). Lack of effect of clenbuterol for delaying parturition in late pregnant mares. Theriogenology 58, 797-799.

Platt H. (1975a). Infection of the horse fetus. Journal of Reproduction and Fertility Suppl 23, 605-610.

Platt H. (1975b). A survey of perinatal mortality and disorders in the Thoroughbred. Animal Health Trust, Newmarket.

Platt H. (1978). Growth and maturity in the equine fetus. Journal of Royal Society of Medicine 1, 658-661.

Peyrou M., Higgins R., Lavoie J.P. (2003). Evolution of bacterial resistence to certain antibacterial agents in horses in a veterinary hospital. Canadian Veterinary Journal 44, 978-981.

Pollard J.K., Mitchell M.D. (1996). Intrauterine infection and the effects of inflammatory mediators on prostaglandin production by myometrial cells from pregnant woman. American Journal of Obstetrics and Gynecology 174, 682-686

Ryan P., Bennet-Wimbush K., Vaala W.E., Bagnell C.A. (1999). Relaxin as a biochemical marker of placental insufficiency in the horse: a review. Pferdeheilkunde 15, 622-626.

Rebello S.A., Macpherson M.L., Murchie T.A., LeBlanc M.M., Vickroy T.A. (2006). Placental transfer of trimetoprim sulfamethoxazole and pentoxifylline in poy mares. Animal Reproduction Science 94, 843-845.

Renaudin C.D., Troedsson M.H., Gilles C.L., King V.L., Bodena A. (1997). Ultrasonographic evaluation of the equine placenta by transrectal and transabdominal approach in the normal pregnant mare. Theriogenology 47, 559-573.

Renaudin C.D., Liu I.K.M., Troedsson M.H.T., Schrenzel M.D. (1999). Transrectal ultrasonographic diagnosis of escending placentitis in the mare: a report of two cases. Equine Veterinary Education 11(2), 69-74.

Romero R., Gomez R., Ghezzi F., Yoon B., Mazor M., Edwin S., Berry S. (1998). A fetal systemic inflammatory response is followed by the spontaneous onset of preterm parturition. American Journal of Obstetrics and Gynecology 179, 186-193.

Rossdale P.D., Silver M. (1982). The concept of readiness for birth. Journal of Reproduction and Fertility Supplement 32, 507-510.

Rossdale P.D., Ousey J.C., Cottrill C.M., Chavatte P., Allen W.R., McGladdery A.J. (1991). Effects of placental pathology on maternal plasma progesterone and mammary secretion calcium secretions and o neonatal adrenocortical function in the horse. Journal of Reproduction and Fertility Supplement 44, 579-590.

Rossdale P.D., McGladdery A.J., Ousey J.C., Holdstock N., Grainger L., Houghton E. (1992). Increae in plasma progestogen concentrations in the mare after foetal injection with CRH, ACTH or betamethasone in late gestation. Equine Veterinary Journal 24, 347-350. 
Ryan P.L., Christiansen D.L., Hopper R.M., Bagnell C.A., Vaala W.E., LeBlanc M.M. (2009). Evaluation of systemic relaxin blood profiles in horses as a means of assessing placental function in high-risk pregnancies and responsiveness to therapeutic strategies. Annals of the New York Academy of Sciences 1160, 169-178.

Santschi E.M., LeBlanc M.M., Weston P.G. (1991). Progestagen, oestrone sulphate and cortisol concentrations in pregnant mares during medical and surgical disease. Journal of Reproduction and Fertility Supplement 44, 627-634.

Schutzer W.E., Kerby J.L., Holtan D.W.(1996). Differential effect of trilostane on the progestin milieu in the pregnant mare. Journal of Reproduction and Fertility 107(2), 241248.

Silver M., Barnes R.J., Comline R.S., Fowden A.I., Clover L., Mitchell M.D. (1979). Prostaglandins in maternal and fetal plasma and in allantoic fluid during the second half of gestation in the mare. Journal of Reproduction and Fertility Supplement 27, 531-539.

Silver M., Fowden A.L. (1988). Induction of labour in domestic animals; endocrine changes and neonatal viability. In: Künzel W., Jensen A. (editors). The Endocrine Control of the Fetus. Berlin: Springer-Verlag, p. 401-411.

Smith K.C., Blunden A.S., Whitwell K.E., Dunn K.A., Wales A.D. (2003). A survey of equine abortion, stillbirth and neonatal death in the UK from 1988-1997. Equine Veterinary Journal 35, 496-501.

Souza A.M., Winter G.H.Z., Garbade P., Wolf C.A., Jobim M.I.M., Gregory R.M., Mattos R.C. (2010). Ultrasonographic evaluation of the Criollo mare placenta. Animal Reproduction Science 121, 320-321.

Steinetz B.G., Beach V.L., Kroc R.L. (1959). The physiology of relaxin in laboratory animals. In: Lloyd C. (editor). Recent Progress in the Endocrinology of Reproduction. Academic Press, New York, NY, pp.389-427.

Stewart D.R., Overstreet J.W., Celniker A.C., Hess D.L., Cragun J.R., Boyers S.P., Lasley B.L. (1993). The rela- tionship between hCG and relaxin secretion in normal pregnancies vs peri-implantation spontaneous abortions. Clinical Endocrinology 38, 379-385.

Stewart D.R., Stabenfeldt G.H., Hughes J.P., Meagher D.M. (1982). Determination of the source of equine relaxin. Biology of Reproduction 27, 17-24.

Troedsson M.H.T., Renaudin C.D., Zent W.W., Stener J.V. (1997). Transrectal ultrasonography of the placenta in normal mares and mares with pending abortion: a field study. In: Proceedings of the American Association of Equine Practitioners. Baltimore, Maryland, USA 43, 256-258.

Troedsson M.H.T. (2001). Ultrasonographic evaluation of the equine placenta. Pferdeheilkunde 17, 583-588.

Troedsson M.H.T. (2003). Placentitis. In: Robertson N.E. (editor). Current Therapy in Equine Medicine. Saunders Philadelphia, pp 297-300.

Watts A.D., Flint A.P.F., Foxcroft G.R., Porter D.G. (1988). Plasma steroid, relaxin and dihydro-keto-prostaglandin F-2 alpha changes in the mini-pig in relation to myometrial electrical and mechanical activity in the pre-partum period. Journal of Reproduction and Fertility 83, 553564.

Weiss D.J., Evanson O.A., Geor R.J. (1994). The effect of furosemide and pentoxifylline on the flow properties of equine erythrocytes - in vitro studies. Veterinary Research Communications 18, 373-381.

Whitwell K.E. (1988). Infective placentitis in the mare. In: Powell D.G. (editor). Equine Infectious Diseases. Proceedings of the fifth International Conference, University Press of Kentucky Lexington KY, pp. 172-180.

Witt B.R., Wolf G.C., Wainwright C., Johnston P.D., Thorneycroft I.H. (1990). Relaxin, CA-125, progesterone, estradiol, Swangerschaft protein, and human gonadotropin as predictors of outcome in threatened and non-threatened pregnancy. Fertility Sterility 53, 1029-1036.

Zent W.W., Williams N.M., Donahue J.M. (1999). Placentitis in central Kentucky broodmares. Pferdeheilkunde 15, 630-632. 